\title{
2-Hydroxy-1-naphthaldehyde-P-hydroxybenzoichydrazone: A New Chromogenic Reagent for the Determination of Thorium(IV) and Uranium(VI)
}

\author{
V. S. Anasuya Devi ${ }^{1}$ and V. Krishna Reddy ${ }^{2}$ \\ ${ }^{1}$ Department of Chemistry, S.E.A. College of Engineering and Technology, Bangalore 560049, India \\ ${ }^{2}$ Department of Chemistry, Sri Krishnadevaraya University, Anantapur 515003, India
}

Correspondence should be addressed to V. S. Anasuya Devi; anukmp@gmail.com

Received 27 June 2012; Accepted 27 September 2012

Academic Editor: Saima Q. Memon

Copyright (c) 2013 V. S. A. Devi and V. K. Reddy. This is an open access article distributed under the Creative Commons Attribution License, which permits unrestricted use, distribution, and reproduction in any medium, provided the original work is properly cited.

\begin{abstract}
Simple, sensitive, selective, direct, derivative, and simultaneous spectrophotometric methods are developed for the determination of uranium and thorium individually and simultaneously. The methods are based on the reaction of 2-hydroxy-1-naphthaldehydep-hydroxybenzoichydrazone (HNAHBH) with thorium(IV) and uranium(VI). HNAHBH reacts with thorium and uranium at pH 6.0 forming stable yellow and reddish brown coloured complexes, respectively. [Th(IV)-HNAHBH] complex shows maximum absorbance at $415 \mathrm{~nm}$. Beer's law is obeyed over the concentration range $0.464-6.961 \mu \mathrm{g} \mathrm{mL}^{-1}$ with a detection limit of $0.01 \mu \mathrm{g} \mathrm{mL}{ }^{-1}$ and molar absorptivity, $\varepsilon, 3.5 \times 10^{4} \mathrm{~L} \mathrm{~mol}^{-1} \mathrm{~cm}^{-1}$. Maximum absorbance shown by [U(VI)-HNAHBH] complex is at $410 \mathrm{~nm}$ with Beer's law range $0.476-7.140 \mu \mathrm{g} \mathrm{mL}^{-1}$, detection limit $0.139 \mu \mathrm{g} \mathrm{mL}^{-1}$ and molar absorptivity, $\varepsilon, 1.78 \times 10^{4} \mathrm{~L} \mathrm{~mol}^{-1} \mathrm{~cm}^{-1}$. Highly sensitive and selective second-order derivative methods are reported for the direct and simultaneous determination of Th(IV) and $\mathrm{U}(\mathrm{VI})$ using HNAHBH. The applicability of the developed methods is tested by analyzing water, ore, fertilizer, and gas mantle samples for thorium and uranium content.
\end{abstract}

\section{Introduction}

Among the various actinides, uranium and thorium due to natural abundance are very important, especially in view of energy sources, but seriously hazardous in view of environmental pollution. Powdered thorium metal is often pyrophoric and should be handled carefully. Exposure to thorium can lead to increased risk of cancers of the lung, pancreas, and blood. Exposure to thorium internally leads to increased risk of liver diseases. All isotopes and compounds of uranium are toxic, teratogenic, and radioactive carcinogens. When uranium gets inside the body, it can lead to cancer or kidney damage. Inhaled uranium increases the risk of lung cancer. There is also the possibility of groundwater contamination with the toxic chemicals used in the separation of the uranium ore. On these considerations measurement of these metals under the microgram levels is very important [1]. Many advanced methods have already been developed for the determination of uranium and thorium.
These methods include alpha spectrometry [2], inductively coupled plasma atomic emission spectrometry (ICP-AES) [3], inductively coupled plasma mass spectrometry (ICP-MS) [4], and capillary zone electrophoresis (CZE) [5]. However, these methods are hampered by less sensitivity or by matrix effect. Furthermore, availability of these techniques is limited due to expensive equipment and higher running cost.

Spectrophotometry is a relatively easy alternative method which provides some advantages, like simplicity and moderately low cost. A number of reagents have been used for the spectrophotometric determination of uranium and thorium. Among the various chromogenic agents reported for the determination of thorium (IV), most of them were found to be nonselective involving in serious interference from the diverse ions [6-9]. Majority of the reported methods require prior removal of closely associated metal ions and hence lack selectivity. Some of the early chromogens employed for the spectrophotometric determination of uranium include Arsenazo-III [10], dibenzoyl methane [11], 


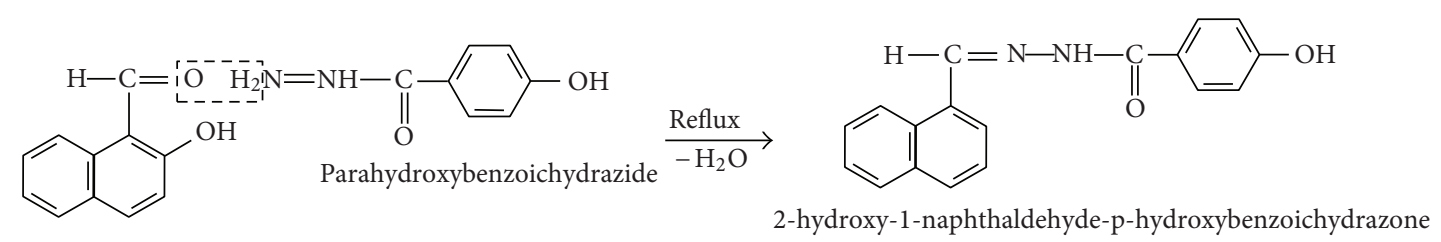

2-hydroxy-1-naphthaldehyde

SCHEMe 1

and 1-(2-pyridylazo)-2-naphthol [12, 13]. They were highly sensitive reagents with less selectivity involving prior separation of interference. In the present investigation simple, sensitive and nonextractive direct and derivative spectrophotometric methods for the determination of thorium and uranium using $\mathrm{HNAHBH}$ are reported. A selective simultaneous second-order derivative spectrophotometric method is also proposed for the determination of Th(IV) and U(VI).

\section{Experimental}

2.1. Reagents. All chemicals used were of analytical-reagent grade. Doubly distilled water was used for preparing aqueous solutions. $0.01 \mathrm{M}$ solution of $\mathrm{U}(\mathrm{VI})$ and $\mathrm{Th}(\mathrm{IV})$ solutions were prepared by dissolving appropriate amounts of uranyl nitrate (Loba) and thorium nitrate (Loba) in $100 \mathrm{~mL}$ distilled water, solutions of lower concentrations were prepared by successive dilution of the stock solution. 1\% cetylpyridiniumchloride (CPC) is used as a cationic surfactant. Buffer solutions of $\mathrm{pH} 1-10$ are prepared using appropriate mixtures of $1 \mathrm{M} \mathrm{CH} \mathrm{CH}_{3} \mathrm{COONa}+1 \mathrm{M} \mathrm{HCl}(\mathrm{pH} 1.0-3.0)$, $0.2 \mathrm{M} \mathrm{CH} \mathrm{CHONa}_{3} \mathrm{CO} 0.2 \mathrm{M} \mathrm{CH} \mathrm{CH}_{3} \mathrm{COOH}(\mathrm{pH} 3.2-6.0$ ), $0.1 \mathrm{M} \mathrm{CH}_{3} \mathrm{COONa}+0.2 \mathrm{M} \mathrm{CH}_{3} \mathrm{COOH}(\mathrm{pH} 7.0)$, and $2 \mathrm{M}$ $\mathrm{NH}_{4} \mathrm{OH}+2 \mathrm{M} \mathrm{NH}_{4} \mathrm{Cl}(\mathrm{pH} 8.0-10.0)$.

2.1.1. Preparation of HNAHBH. 2-hydroxy-1-naphthaldehyde in methanol was mixed with p-benzoichydrazide in hot aqueous ethanol in equal amounts and refluxed for three hours on water bath. A reddish brown coloured solid was obtained on cooling. The product was filtered and dried. It was recrystallized from aqueous ethanol in the presence of norit. The product showed melting point $272-274^{\circ} \mathrm{C}$. The structure of the synthesized 2-Hydroxy-1-naphthaldehydep-hydroxybenzoichydrazone (HNAHBH) was determined from infrared and NMR spectral analysis. $1 \times 10^{-2} \mathrm{M}$ solution of the reagent was prepared by dissolving $0.306 \mathrm{~g}$ in $100 \mathrm{~mL}$ of dimethylformamide (DMF). Working solutions were prepared by diluting the stock solution with DMF (Scheme 1).

\subsection{Sample Solutions}

2.2.1. Preparation of Monazite Sand Sample [26]. The monazite sand was collected from the Arabian Sea coast at Mangalore, India. $1.0 \mathrm{~g}$ of the monazite sand was mixed with $5 \mathrm{~mL}$ of concentrated sulphuric acid and heated at $250^{\circ} \mathrm{C}$ for about 4 hours to digest the monazite sand. The resultant viscous paste was dissolved in distilled water by heating at $45^{\circ} \mathrm{C}$ for half an hour. The resultant solution was filtered and thorium from the filtrate is precipitated as hydroxide by adding ammonia solution. The precipitate was filtered off and dissolved in minimum quantity of dil $\mathrm{HCl}$ and then diluted to $25 \mathrm{~mL}$.

2.2.2. Preparation of Gas Mantle Sample [27]. $0.5 \mathrm{~g}$ of gas mantle sample was accurately weighed and placed in a $100 \mathrm{~mL}$ beaker. $10 \mathrm{~mL}$ of con $\mathrm{HNO}_{3}$ was added and gently boiled for 20 minutes. The residue was diluted with $10 \mathrm{~mL}$ of distilled water and filtered. The resultant solution was diluted to $250 \mathrm{~mL}$ in a volumetric flask with distilled water.

2.2.3. Preparation of Phosphate Rock and Fertilizer Sample $[28,29]$. The phosphate rock which is the raw material for manufacturing of phosphate fertilizers, NPK and DAP fertilizers, was collected from a fertilizer industry, Anantapur, India. The collected samples were finely grounded. $10 \mathrm{~g}$ of each sample was transferred separately into Ernermeyers flask containing $100 \mathrm{~mL}$ of $0.1 \mathrm{M}$ critic acid. All these flasks were incubated in the orbital shaker at $30^{\circ} \mathrm{C}$ at $100 \mathrm{rev} \mathrm{min}{ }^{-1}$. These samples were removed and centrifuged to remove solid suspension.

2.2.4. Preparation of Ore Solution [30]. $0.25 \mathrm{~g}$ of 20283 MALINIM-G (Granite) or 20383 MALINIM-L (Lujavrite) ore samples was weighed and dissolved in a mixture of $15 \mathrm{~mL}$ of con $\mathrm{H}_{2} \mathrm{SO}_{4}, 5 \mathrm{~mL}$ of con. $\mathrm{HNO}_{3}$, and $45 \mathrm{~mL}$ of $\mathrm{HF}$ by boiling in a teflon beaker. The solution was evaporated to dryness, and the residue was dissolved in $10 \mathrm{~mL}$ of distilled water.

2.2.5. Preparation of Water Samples. Natural water samples from different sources of Anantapur town were collected and filtered through Whatman filter paper no. 41 to remove the suspended particulate matter. The filtered water was then treated with $5 \mathrm{~mL}$ of con. $\mathrm{HNO}_{3}$ to prevent the possible hydrolytic precipitation of some mineral salts. Different known amounts of $\mathrm{U}(\mathrm{VI})$ and $\mathrm{Th}(\mathrm{IV})$ were then spiked into $100 \mathrm{~mL}$ of these treated water samples.

2.3. Apparatus. A Perkin Elmer (LAMBDA25) spectrophotometer controlled by a computer and equipped with a $1 \mathrm{~cm}$ path length quartz cell was used for UV-Vis spectra acquisition. Spectra were acquired between 350-600 nm (1 nm resolution). An ELICO model LI-120 pH-meter furnished with a combined glass electrode was used to measure $\mathrm{pH}$ of buffer solutions. 
TABLE 1: Tolerance limits of foreign ions. Amount of Th(IV) taken $=0.928 \mu \mathrm{g} \mathrm{mL}^{-1} \mathrm{pH}=6.0$.

\begin{tabular}{|c|c|c|c|c|c|}
\hline Foreign ion & $\begin{array}{l}\text { Tolerance limit } \\
\quad\left(\mu \mathrm{gL}^{-1}\right)\end{array}$ & Foreign ion & $\begin{array}{l}\text { Tolerance limit } \\
\quad\left(\mu \mathrm{g} \mathrm{mL} L^{-1}\right)\end{array}$ & Foreign ion & $\begin{array}{l}\text { Tolerance limit } \\
\quad\left(\mu \mathrm{g} \mathrm{mL} L^{-1}\right)\end{array}$ \\
\hline Iodide & 1904 & $\mathrm{Ba}(\mathrm{II})$ & 1650 & $\mathrm{Hg}(\mathrm{II})$ & 20 \\
\hline EDTA & 1861 & $\mathrm{Na}(\mathrm{I})$ & 1500 & $\mathrm{Ru}(\mathrm{III})$ & 20 \\
\hline Thiosulphate & 1680 & $\mathrm{~K}(\mathrm{I})$ & 1400 & $\mathrm{Mn}(\mathrm{II})$ & 11 \\
\hline Sulphate & 1440 & $\mathrm{Ca}(\mathrm{II})$ & 1140 & $\mathrm{Zr}(\mathrm{IV})$ & 10 \\
\hline Bromide & 1215 & $\operatorname{Mg}(\mathrm{II})$ & 1000 & $\mathrm{Sn}(\mathrm{II})$ & 10 \\
\hline Citrate & 945 & $\mathrm{~W}(\mathrm{VI})$ & 55 & $\operatorname{Sr}(\mathrm{II})$ & 9 \\
\hline Nitrate & 930 & $\mathrm{Hf}(\mathrm{IV})$ & 54 & $\mathrm{Cr}(\mathrm{VI})$ & 6 \\
\hline Tartrate & 740 & $\mathrm{~Pb}(\mathrm{II})$ & 42 & $\mathrm{Cu}(\mathrm{II})$ & 5 \\
\hline Thiocyanate & 870 & $\operatorname{Ti}(\mathrm{IV})$ & 40 & $\mathrm{Ni}(\mathrm{II})$ & $<1,55^{\mathrm{a}}$ \\
\hline Carbonate & 600 & $\mathrm{Au}(\mathrm{III})$ & 40 & $\mathrm{Co}(\mathrm{II})$ & $<1,100^{\mathrm{a}}$ \\
\hline Chloride & 533 & $\mathrm{Te}(\mathrm{IV})$ & 40 & $\mathrm{Zn}(\mathrm{II})$ & $<1,60^{\mathrm{a}}$ \\
\hline Phosphate & 475 & $\mathrm{Cd}(\mathrm{II})$ & 34 & $\mathrm{Bi}(\mathrm{III})$ & $<1,150^{\mathrm{a}}$ \\
\hline Thiourea & 380 & $\mathrm{Se}(\mathrm{IV})$ & 31 & $\mathrm{Fe}(\mathrm{II})$ & $<1,60^{\mathrm{a}}$ \\
\hline Oxalate & 280 & $\mathrm{Mo}(\mathrm{VI})$ & 29 & $\mathrm{Al}(\mathrm{III})$ & $<1,120^{\mathrm{b}}$ \\
\hline \multirow[t]{3}{*}{ Fluoride } & 95 & $\mathrm{La}(\mathrm{III})$ & 28 & $\mathrm{U}(\mathrm{VI})$ & $<1,70^{\mathrm{b}}$ \\
\hline & & $\operatorname{Pd}(\mathrm{II})$ & 22 & $\operatorname{In}(\mathrm{III})$ & $<1,50^{\mathrm{b}}$ \\
\hline & & $\operatorname{Ag}(\mathrm{I})$ & 22 & $\mathrm{Ga}(\mathrm{III})$ & $<1,60^{\mathrm{b}}$ \\
\hline
\end{tabular}

Masking agents, ${ }^{a}$ in the presence of $800 \mathrm{ppm}$ of EDTA; ${ }^{b} 500 \mathrm{ppm}$ of tartrate.

\section{Results and Discussions}

3.1. Direct Spectrophotometric Determination of Thorium(IV) and Uranium(VI). HNAHBH forms yellow and reddish brown coloured complexes with $\mathrm{Th}(\mathrm{IV})$ and $\mathrm{U}(\mathrm{VI})$, respectively. The colour of complexes is stable for more than 72 hours. Influence of $\mathrm{pH}$, reagent, and surfactants on the absorbance of the complexes was investigated as follows.

3.1.1. $p H$ Effect. The study of effect of $\mathrm{pH} 1.0-10.0$ on the absorbance of both the reaction mixtures [U(VI)-HNAHBH] and [Th(IV)-HNAHBH] showed that maximum absorbance was obtained in the $\mathrm{pH}$ region of 5.5-6.5. Therefore further studies were carried out at $\mathrm{pH} 6.0$.

3.1.2. Effect of Reagent (HNAHBH) Concentration. A 15-fold excess reagent $(\mathrm{HNAHBH})$ is sufficient to develop maximum and stable colour for Th(IV) whereas 20 -fold excess reagent ( $\mathrm{HNAHBH})$ is required for $\mathrm{U}(\mathrm{VI})$.

3.1.3. Surfactant Effect. $0.15 \%$ of CPC enhances the colour and stability of [U(VI)-HNAHBH] complex. [Th(IV)HNAHBH] complex has no surfactant influence.

3.1.4. Absorption Spectra. The absorption spectra of [Th(IV)$\mathrm{HNAHBH}]$ and $[\mathrm{U}(\mathrm{VI})-\mathrm{HNAHBH}$ ] complexes in presence of suitable buffer, surfactant, and reagent were recorded. [Th(IV)-HNAHBH] complex shows maximum absorbance at $415 \mathrm{~nm}$ and that of [U(VI)-HNAHBH] complex is at $410 \mathrm{~nm}$. Reagent blank shows the least absorbance at these wave lengths.
3.1.5. Calibration Curves. The calibration curves were constructed for both the complexes taking variable amounts of metal ions at their respective absorption maxima. The calibration plots were linear over wide concentration ranges which are shown in Table 10 along with the slope, intercept, standard deviation, detection, and determination limits.

3.1.6. Composition of the Complex. The stoichiometry of the complex [metal:reagent] was determined by job's method, mole ratio method, and slope ratio methods and is found to be $1: 1$ for [U(VI):HNAHBH] and $2: 3$ for [Th(IV) : HNAHBH].

3.1.7. Interferences. The effect of diverse ions in the determination of Th(IV) and U(VI) was studied in detail, and the tolerance limits were calculated and presented in Tables 1 and 2. Most of the anions and good number of cations did not interfere in the present methods even when present in more than 50-fold excess. Some cations, which interfere seriously, could be masked up to 50 -fold excess with suitable masking agents as shown in the Tables 1 and 2.

3.1.8. Application of Proposed Direct Methods. The proposed direct spectrophotometric methods were employed for the determination of thorium in monazite sand and environmental water samples and for the determination of uranium in phosphate rock and fertilizer samples.

Suitable aliquots of prepared sample solutions are treated with required amount of reagent and suitable buffer media, and the absorbances of resultant solutions were measured at appropriate wave lengths; the amounts of metal ions present 
TABLE 2: Tolerance limits of foreign ions. Amount of $\mathrm{U}(\mathrm{VI})$ taken $=4.760 \mu \mathrm{g} \mathrm{mL} \mathrm{L}^{-1} \mathrm{pH}=6.0$.

\begin{tabular}{|c|c|c|c|c|c|}
\hline Foreign ion & $\begin{array}{l}\text { Tolerance limit } \\
\quad\left(\mu \mathrm{g} \mathrm{mL}^{-1}\right)\end{array}$ & Foreign ion & Tolerance limit & Foreign ion & $\begin{array}{c}\text { Tolerance limit } \\
\left(\mu \mathrm{g} \mathrm{mL}^{-1}\right)\end{array}$ \\
\hline Tartrate & 1480 & $\mathrm{~K}(\mathrm{I})$ & 1760 & $\mathrm{Hg}(\mathrm{II})$ & 20 \\
\hline Sulphate & 1440 & $\mathrm{Ca}(\mathrm{II})$ & 1560 & $\mathrm{Ru}(\mathrm{III})$ & 20 \\
\hline Phosphate & 1430 & $\operatorname{Mg}(\mathrm{II})$ & 1510 & $\mathrm{Mn}(\mathrm{II})$ & 11 \\
\hline Thiosulphate & 1200 & $\mathrm{Na}(\mathrm{I})$ & 1450 & $\mathrm{Zr}(\mathrm{IV})$ & 10 \\
\hline Bromide & 1200 & $\mathrm{Ba}(\mathrm{II})$ & 1170 & $\operatorname{Sn}(\mathrm{II})$ & 10 \\
\hline Thiourea & 1140 & $\mathrm{Hf}(\mathrm{IV})$ & 72 & $\operatorname{Sr}(\mathrm{II})$ & 9 \\
\hline Nitrate & 960 & $\mathrm{~W}(\mathrm{VI})$ & 55 & $\mathrm{Cr}(\mathrm{VI})$ & 7 \\
\hline Thiocyanate & 870 & $\mathrm{~Pb}(\mathrm{II})$ & 42 & $\mathrm{Ni}(\mathrm{II})$ & $3,55^{\mathrm{b}}$ \\
\hline Iodide & 734 & $\operatorname{Ti}(\mathrm{IV})$ & 40 & $\mathrm{Cu}(\mathrm{II})$ & $2,65^{\mathrm{a}}$ \\
\hline Oxalate & 440 & $\mathrm{Au}(\mathrm{III})$ & 40 & $\mathrm{Co}(\mathrm{II})$ & $2,100^{\mathrm{a}}$ \\
\hline Chloride & 360 & $\mathrm{Te}(\mathrm{IV})$ & 40 & $\mathrm{Zn}(\mathrm{II})$ & $2,60^{c}$ \\
\hline Carbonate & 300 & $\mathrm{Cd}(\mathrm{II})$ & 34 & $\mathrm{Bi}(\mathrm{III})$ & $0.6,75^{\mathrm{a}}$ \\
\hline Fluoride & 290 & $\mathrm{Se}(\mathrm{IV})$ & 31 & $\mathrm{Fe}(\mathrm{II})$ & $0.6,60^{\mathrm{a}}$ \\
\hline EDTA & 236 & $\mathrm{Mo}(\mathrm{VI})$ & 29 & $\mathrm{Al}(\mathrm{III})$ & $0.3,60^{\mathrm{a}}$ \\
\hline Ascorbate & 190 & $\mathrm{La}(\mathrm{III})$ & 28 & $\operatorname{Th}(\mathrm{IV})$ & $0.3,70^{\mathrm{a}}$ \\
\hline \multirow[t]{2}{*}{ Citrate } & 136 & $\mathrm{Pd}(\mathrm{II})$ & 22 & $\operatorname{In}(\mathrm{III})$ & $0.4,50^{\mathrm{a}}$ \\
\hline & & $\operatorname{Ag}(\mathrm{I})$ & 22 & $\mathrm{Ga}(\mathrm{III})$ & $0.3,60^{\mathrm{a}}$ \\
\hline
\end{tabular}

Masking agents, ${ }^{\mathrm{a}}$ in presence of $600 \mathrm{ppm}$ of Tartrate, ${ }^{\mathrm{b}} 300 \mathrm{ppm}$ of oxalate, ${ }^{\mathrm{c}} 500 \mathrm{ppm}$ of thiocyanate.

TABLE 3: Determination of thorium in monazite sand samples.

\begin{tabular}{lccc}
\hline \multirow{2}{*}{ Sample } & \multicolumn{3}{c}{ Amount of thorium $\left(\mu \mathrm{g} \mathrm{mL}^{-1}\right) \pm \mathrm{SD}^{*}$} \\
& Present method & AAS method & Relative error (\%) \\
\hline S1 & $2.29 \pm 2.20$ & $2.20 \pm 0.56$ & 4.10 \\
S2 & $5.08 \pm 1.68$ & $4.90 \pm 2.14$ & 3.67 \\
S3 & $3.22 \pm 1.68$ & $3.26 \pm 0.56$ & -1.25 \\
\hline " Average of three determinations.
\end{tabular}

TABLE 4: Determination of thorium in environmental water samples.

\begin{tabular}{|c|c|c|c|}
\hline \multirow[t]{2}{*}{ Sample } & \multicolumn{3}{|c|}{$\begin{array}{l}\text { Amount of thorium }\left(\mu \mathrm{g} \mathrm{mL}^{-1}\right) \pm \mathrm{SD} \\
\qquad(n=4)\end{array}$} \\
\hline & Added & Found & Recovery \% \\
\hline Tap water & 1.5 & $1.55 \pm 0.84$ & 103.30 \\
\hline Bore-well water & 2.0 & $2.19 \pm 1.56$ & 109.50 \\
\hline Stream water & 4.5 & $4.44 \pm 1.16$ & 98.60 \\
\hline Domestic sewage water & 3.5 & $3.62 \pm 1.88$ & 103.42 \\
\hline
\end{tabular}

in samples are computed from the measured absorbance values and predetermined calibration plots. The results are presented in Tables 3, 4, and 5. The results are further compared with those obtained by AAS method, and relative errors are calculated and presented.

3.2. Derivative Spectrophotometric Determination of Th(IV) and $U(V I)$. Second-order derivative spectra at $\mathrm{pH} 6.0$ in the wavelength region of $350-600 \mathrm{~nm}$ is recorded for
TABLE 5: Analysis of phosphate rock and fertilizers for their uranium content.

\begin{tabular}{lcc}
\hline Sample & \multicolumn{2}{c}{ Uranium content $\left(\mathrm{mg} \mathrm{kg}^{-1}\right)$} \\
& $\begin{array}{c}\text { Proposed method } \pm \text { SD } \\
(n=4)\end{array}$ & $\begin{array}{c}\text { AAS method } \pm \text { SD } \\
(n=2)\end{array}$ \\
\hline $\begin{array}{l}\text { Phosphate rock } \\
\text { (India) }\end{array}$ & $33.96 \pm 0.032$ & $35.26 \pm 0.018$ \\
NPK fertilizer & $19.25 \pm 0.010$ & $17.95 \pm 0.012$ \\
DAP fertilizer & $49.95 \pm 0.024$ & $50.06 \pm 0.022$ \\
\hline
\end{tabular}

TABLE 6: Tolerance limits of foreign ions. [Th(IV)-HNAHBH] system.

\begin{tabular}{lcc}
\hline Foreign ion & \multicolumn{2}{c}{ Tolerance limit (in folds) } \\
& Zero order & Second derivative \\
\hline $\mathrm{Cu}(\mathrm{II})$ & 5 & 25 \\
$\mathrm{Ni}(\mathrm{II})$ & $<1$ & 20 \\
$\mathrm{Co}(\mathrm{II})$ & $<1$ & 18 \\
$\mathrm{Zn}(\mathrm{II})$ & $<1$ & 22 \\
$\mathrm{Bi}(\mathrm{III})$ & $<1$ & 12 \\
$\mathrm{Fe}(\mathrm{II})$ & $<1$ & 45 \\
$\mathrm{Al}(\mathrm{III})$ & $<1$ & 60 \\
$\mathrm{U}(\mathrm{VI})$ & $<1$ & 35 \\
$\mathrm{In}(\mathrm{III})$ & $<1$ & 30 \\
$\mathrm{Ga}(\mathrm{III})$ & $<1$ & 40 \\
\hline
\end{tabular}

both [Th(IV): HNAHBH] and [U(VI)-HNAHBH] complexes (Figures 1 and 2). The second-order derivative spectra 
TABLE 7: Tolerance limits of foreign ions. [U(VI)-HNAHBH] system.

\begin{tabular}{lcc}
\hline Foreign ion & \multicolumn{2}{c}{ Tolerance limit (in folds) } \\
& Zero order & Second derivative \\
\hline $\mathrm{Ni}(\mathrm{II})$ & 3 & 10 \\
$\mathrm{Cu}(\mathrm{II})$ & 2 & 15 \\
$\mathrm{Co}(\mathrm{II})$ & 2 & 15 \\
$\mathrm{Zn}(\mathrm{II})$ & 2 & 8 \\
$\mathrm{Bi}(\mathrm{III})$ & $<1$ & 20 \\
$\mathrm{Fe}(\mathrm{II})$ & $<1$ & 30 \\
$\mathrm{Al}(\mathrm{III})$ & $<1$ & 25 \\
$\mathrm{Th}(\mathrm{IV})$ & $<1$ & 35 \\
$\mathrm{In}(\mathrm{III})$ & $<1$ & 30 \\
$\mathrm{Ga}(\mathrm{III})$ & $<1$ & 50 \\
\hline
\end{tabular}

TABLE 8: Determination of thorium in gas mantle.

\begin{tabular}{lccc}
\hline \multirow{3}{*}{ Sample } & \multicolumn{3}{c}{$\begin{array}{c}\text { Amount of thorium }\left(\mu \mathrm{g} \mathrm{L}^{-1}\right) \pm \mathrm{SD} \\
(n=4)\end{array}$} \\
& Added & Found & Recovery \% \\
\hline \multirow{3}{*}{ Sample 1 } & - & $1.54 \pm 0.83$ & - \\
& 0.5 & $2.15 \pm 1.84$ & 98.62 \\
& 1.5 & $3.14 \pm 2.24$ & 98.70 \\
& 2.5 & $3.94 \pm 1.10$ & 94.20 \\
\hline \multirow{3}{*}{ Sample 2 } & 0.5 & $2.42 \pm 1.15$ & - \\
& 1.5 & $3.14 \pm 1.68$ & 118.49 \\
& 2.5 & $3.78 \pm 2.64$ & 103.56 \\
& & $4.82 \pm 1.48$ & 103.65 \\
\hline
\end{tabular}

TABLE 9: Analysis of environmental water samples.

\begin{tabular}{lccc}
\hline Sample & $\begin{array}{c}\text { Uranium added } \\
\left(\mu \mathrm{g} \mathrm{mL}^{-1}\right)\end{array}$ & \multicolumn{2}{c}{ Uranium found $\left(\mu \mathrm{g} \mathrm{m}^{-1}\right) \pm \mathrm{SD}^{*}$} \\
Found & Recovery $(\%)$ \\
\hline \multirow{3}{*}{ Tap water } & 0.5 & $0.51 \pm 0.010$ & 102.0 \\
& 2.5 & $2.48 \pm 0.016$ & 99.2 \\
& 5.0 & $4.96 \pm 0.018$ & 99.2 \\
\hline \multirow{3}{*}{ Well water } & 0.5 & $0.49 \pm 0.013$ & 98.0 \\
& 2.5 & $2.47 \pm 0.018$ & 98.8 \\
\multirow{3}{*}{ Waste water } & 5.0 & $4.97 \pm 0.011$ & 99.4 \\
& 0.5 & $0.48 \pm 0.018$ & 96.0 \\
& 2.5 & $2.52 \pm 0.022$ & 100.8 \\
\hline
\end{tabular}

Average of four determinations.

of [Th(IV): HNAHBH] complex show maximum amplitude at $434 \mathrm{~nm}$ and $453 \mathrm{~nm}$ with zero crossing at $443 \mathrm{~nm}$ (Figure 1). The second derivative spectra of yellowish brown coloured [U(VI)-HNAHBH] solution show a small crust at $448 \mathrm{~nm}$, a small trough at $459 \mathrm{~nm}$, and an intensified crust at $477 \mathrm{~nm}$ with zero cross at $453 \mathrm{~nm}$ and $466 \mathrm{~nm}$ (Figure 2). The measured derivative amplitudes at appropriate wavelengths as mentioned above for second derivative spectra were plotted against the amount of $\mathrm{Th}(\mathrm{IV})$ and $\mathrm{U}(\mathrm{VI})$. Linear

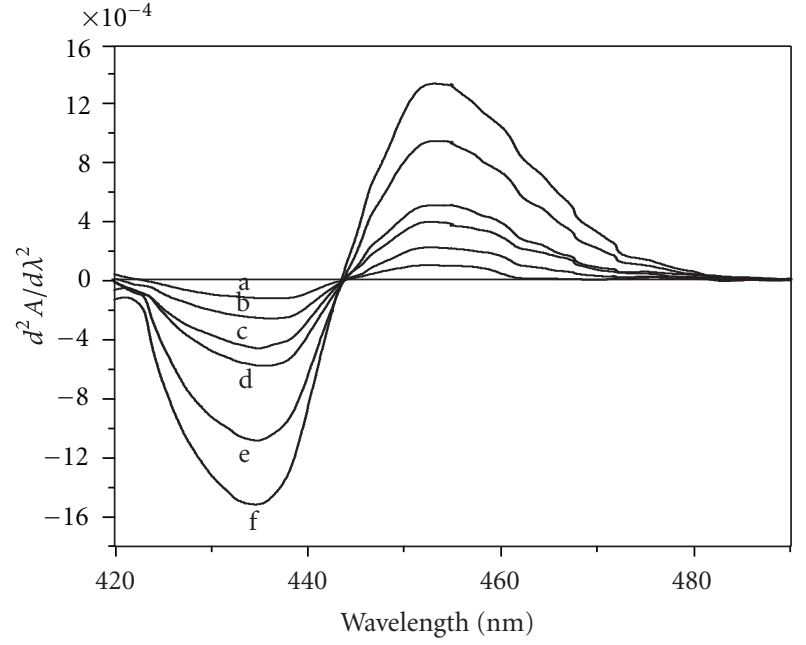

FIGURE 1: Second-order derivative spectra of [Th(IV)-HNAHBH]. Amount of Th(IV) $\mu \mathrm{g} \mathrm{mL}^{-1}: \mathrm{a}=0.234, \mathrm{~b}=0.464, \mathrm{c}=0.696, \mathrm{~d}=0.928$, $\mathrm{e}=0.139$, and $\mathrm{f}=1.856$.

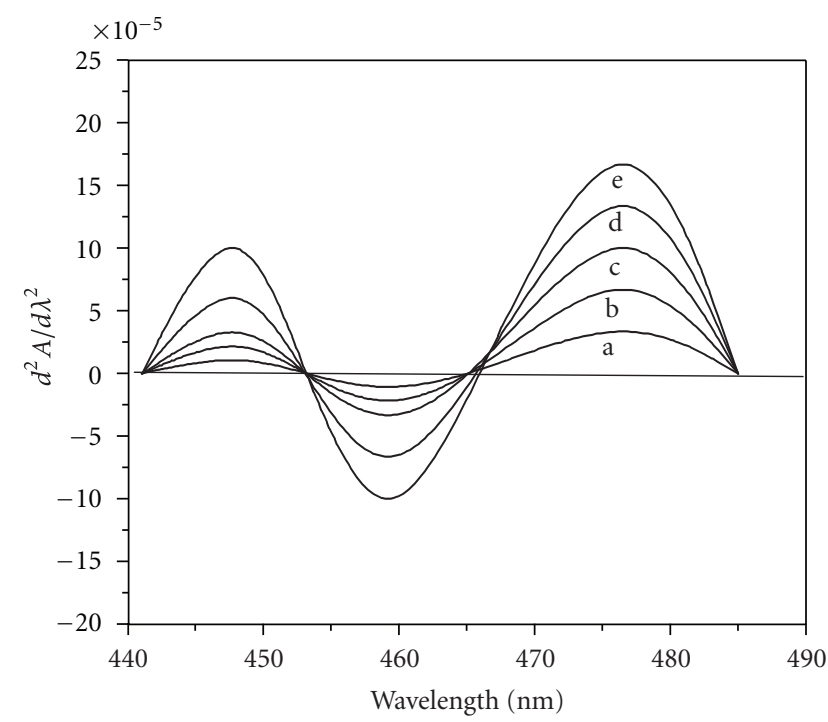

FIgURE 2: Second-order derivative spectra of [U(VI)-HNAHBH]. Amount of $\mathrm{U}(\mathrm{VI}) \mu \mathrm{g} \mathrm{mL}^{-1}: \mathrm{a}=0.238 ; \mathrm{b}=0.476 ; \mathrm{c}=0.952 ; \mathrm{d}=1.428$; $\mathrm{e}=1.904$.

plots were obtained in the range of $0.232-6.961 \mu \mathrm{g} \mathrm{mL}^{-1}$ for $\mathrm{Th}(\mathrm{IV})$ and $0.238-2.38 \mu \mathrm{g} \mathrm{mL}^{-1}$ for $\mathrm{U}(\mathrm{VI})$. Other analytical properties are listed in Table 10.

3.2.1. Effect of Foreign Ions in Derivative Methods. Interference of various metal and anions were studied on the derivative amplitudes. It was noticed that all metal ions and anions which did not interfere in direct methods also did not interfere in derivative methods. The metal ions which interfere seriously in zero order method are tolerable up to 20-25 fold excess (Tables 6 and 7). The above studies reveal that the derivative methods are more sensitive and selective than proposed direct methods. 
TABLE 10: Analytical properties of [Th(IV)-HNAHBH] and [U(VI)-HNAHBH].

\begin{tabular}{|c|c|c|c|c|c|c|}
\hline \multirow{3}{*}{ Parameter } & \multicolumn{2}{|c|}{ Direct method } & \multicolumn{4}{|c|}{ Second derivative } \\
\hline & \multirow{2}{*}{$\begin{array}{l}\text { Thorium } \\
415 \mathrm{~nm}\end{array}$} & \multirow{2}{*}{$\begin{array}{l}\text { Uranium } \\
410 \mathrm{~nm}\end{array}$} & \multicolumn{2}{|c|}{ Thorium } & \multicolumn{2}{|c|}{ Uranium } \\
\hline & & & $434 \mathrm{~nm}$ & $453 \mathrm{~nm}$ & $459 \mathrm{~nm}$ & $477 \mathrm{~nm}$ \\
\hline Beer's law range $\left(\mu \mathrm{g} \mathrm{mL}^{-1}\right)$ & $0.464-6.961$ & $0.476-7.140$ & $0.232-6.961$ & $0.232-6.961$ & $0.238-2.38$ & $0.238-2.38$ \\
\hline Molar absorptivity, $\left(\mathrm{L} \mathrm{mol}^{-1} \mathrm{~cm}^{-1}\right)$ & $3.5 \times 10^{4}$ & $1.78 \times 10^{4}$ & - & - & - & - \\
\hline Sandell's sensitivity, $\mu \mathrm{g} \mathrm{cm}^{-2}$ & 0.007 & 0.0134 & - & - & - & - \\
\hline Angular coefficient $(m)$ & 0.365 & 0.0827 & 0.0007 & 0.0006 & 0.0001 & 0.0001 \\
\hline$Y$-intercept $(b)$ & 0.0013 & 0.0081 & $-0.9 \times 10^{-3}$ & $-0.9 \times 10^{-3}$ & $-0.6 \times 10^{-4}$ & $0.5 \times 10^{-4}$ \\
\hline Correlation coefficient $(r)$ & 0.9999 & 0.9994 & 0.9998 & 0.9998 & 0.9999 & 0.9999 \\
\hline RSD & 0.335 & $1.65 \%$ & 1.46 & 0.17 & $0.98 \%$ & 2.25 \\
\hline Detection limit $\left(\mu \mathrm{g} \mathrm{mL}^{-1}\right)$ & 0.01 & 0.139 & 0.014 & 0.044 & 0.03 & 0.067 \\
\hline Determination limit, $\mu \mathrm{g} \mathrm{mL}^{-1}$ & 0.03 & 0.417 & 0.043 & 0.132 & 0.09 & 0.2 \\
\hline Composition (M:L) & $2: 3$ & $1: 1$ & - & - & - & - \\
\hline Stability constant & $2.72 \times 10^{19}$ & $3.3 \times 10^{5}$ & - & - & - & - \\
\hline
\end{tabular}

\subsection{Application of Proposed Derivative Methods}

3.3.1. Determination of Thorium in Gas Mantle. A known aliquot of the prepared sample solution was treated according to the recommended procedure, and the amount of thorium was evaluated from the predetermined calibration plot. The results are shown in Table 8 along with recovery percentages.

3.3.2. Analysis of Environmental Water Samples for the Uranium Content. $100 \mathrm{~mL}$ of each of the sample was filtered using Whatman filter paper and spiked with known amounts of uranium. Suitable aliquots were taken and analysed for uranium amount (Table 9).

3.4. Simultaneous Second-Order Derivative Spectrophotometric Determination of Uranium and Thorium. A good number of spectrophotometric methods have already been developed for the simultaneous determination of uranium and thorium [31-33]. The present method provides a simple and selective derivative spectrophotometric procedure for the simultaneous determination of uranium and thorium without prior separation and without solving simultaneous equations.

3.4.1. Derivative Spectra. The 2 nd-order derivative spectra recorded for [U(VI)-HNAHBH] and [Th(VI)-HNAHBH] at $\mathrm{pH} 6.0$ showed sufficiently large derivative amplitude for thorium at $448 \mathrm{~nm}$, while the U(VI) species exhibits zero amplitude, at $477 \mathrm{~nm}$ maximum derivative amplitude was noticed for U(VI) where there is no amplitude for Th(IV) (Figure 3). This facilitates the determination of U(VI) and Th(IV) simultaneously by measuring the second derivative amplitudes of binary mixtures containing U(VI) and Th(IV) at $477 \mathrm{~nm}$ and $448 \mathrm{~nm}$, respectively.

3.4.2. Determination of $U(V I)$ and $T h(I V)$. Aliquots of solutions containing $0.238-2.380 \mu \mathrm{g} \mathrm{mL}^{-1}$ of $\mathrm{U}(\mathrm{VI})$ or $0.232-4.640 \mu \mathrm{g} \mathrm{mL}^{-1}$ of $\mathrm{Th}(\mathrm{IV})$ were transferred into a series of $10 \mathrm{~mL}$ calibrated volumetric flasks. HNAHBH $(1 \times$ $\left.10^{-2} \mathrm{M}, 0.6 \mathrm{~mL}\right), \mathrm{CPC}(1 \%, 0.5 \mathrm{~mL})$, and buffer solution

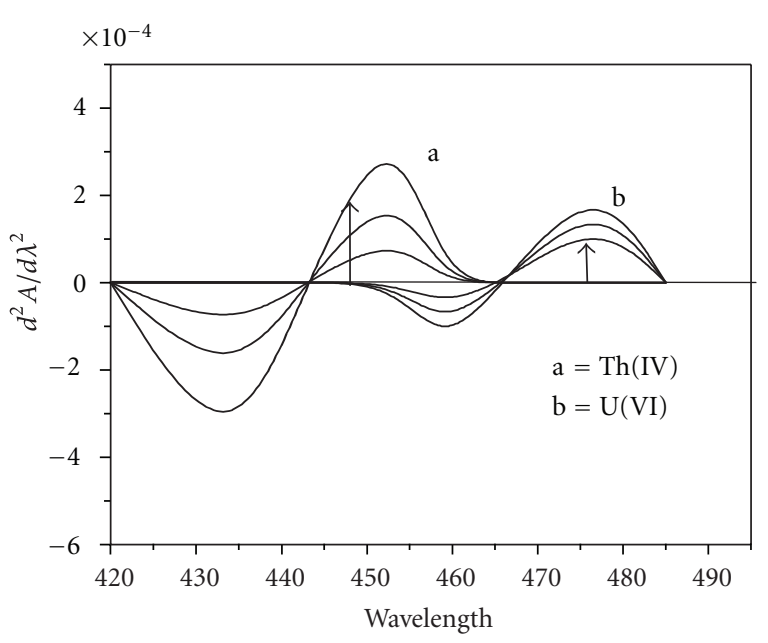

FIGURE 3: Second order derivative spectra of (a) [Th(IV)HNAHBH] and (b) [U(VI)-HNAHBH]. Th(IV) $\left(\mu \mathrm{g} \mathrm{mL}^{-1}\right): 0.464$; 0.928; 1.392: U(VI) $\left(\mu \mathrm{g} \mathrm{mL}^{-1}\right): 0.952 ; 1.428 ; 1.904$.

( $\mathrm{pH} 6.0,4 \mathrm{~mL})$ were added to each of these flasks and diluted to the mark with distilled water. The zero crossing points of [U(VI)-HNAHBH] and [Th(IV)-HNAHBH] species were determined by recording the second-order derivative spectra of both the systems with reference to the reagent blank. Calibration plots for the determination of $\mathrm{U}(\mathrm{VI})$ and $\mathrm{Th}(\mathrm{IV})$ were constructed by measuring the second derivative amplitudes at zero crossing points of [Th(IV)-HNAHBH] $(448 \mathrm{~nm})$ and [U(VI)-HNAHBH] $(477 \mathrm{~nm})$, respectively and plotting against the respective analyte concentrations. [U(VI)-HNAHBH] and [Th(IV)$\mathrm{HNAHBH}$ ] coloured solutions obeyed Beer's law in the range $0.238-2.380 \mu \mathrm{g} \mathrm{mL}^{-1}$ and $0.232-4.640 \mu \mathrm{g} \mathrm{mL}^{-1}$ at $477 \mathrm{~nm}$ and $448 \mathrm{~nm}$, respectively. To test the mutual independency of the analytical signals of $U(V I)$ and Th(IV) in the presence of each other, the calibration plots were drawn for each metal ion alone and in the presence of a known amount of the other metal ion. The slopes, intercepts, and correlation 
TABLE 11: Linear regression analysis of the determination of $\mathrm{U}(\mathrm{VI})$ and $\mathrm{Th}(\mathrm{IV})$ in mixture by second derivative spectrophotometry.

\begin{tabular}{|c|c|c|c|c|c|c|}
\hline \multirow{2}{*}{ Metal ion determined } & \multirow{2}{*}{ Wave length (nm) } & \multicolumn{2}{|c|}{ Other metals present $\left(\mu \mathrm{g} \mathrm{mL}^{-1}\right)$} & \multirow{2}{*}{ Slope } & \multirow{2}{*}{ Intercept } & \multirow{2}{*}{ Correlation coefficient } \\
\hline & & $\mathrm{U}(\mathrm{VI})$ & $\operatorname{Th}(\mathrm{IV})$ & & & \\
\hline \multirow{2}{*}{ Uranium(VI) } & 477 & & & $1.0 \times 10^{-4}$ & $5 \times 10^{-5}$ & 0.9998 \\
\hline & & & 1.856 & $0.9 \times 10^{-4}$ & $4 \times 10^{-5}$ & 0.9996 \\
\hline \multirow{2}{*}{ Thorium(IV) } & 448 & & & $6.9 \times 10^{-4}$ & $-1.0 \times 10^{-6}$ & 0.9999 \\
\hline & & 1.908 & & $5.8 \times 10^{-4}$ & $-0.8 \times 10^{-6}$ & 0.9998 \\
\hline
\end{tabular}

TABLE 12: Simultaneous determination of $\mathrm{U}(\mathrm{VI})$ and $\mathrm{Th}(\mathrm{IV})$ in binary mixtures.

\begin{tabular}{|c|c|c|c|c|c|}
\hline \multicolumn{2}{|c|}{ Amount taken $\left(\mu \mathrm{g} \mathrm{mL}^{-1}\right)$} & \multicolumn{2}{|c|}{ Amount found ${ }^{*}\left(\mu \mathrm{g} \mathrm{mL}^{-1}\right)($ recovery $\%)$} & \multicolumn{2}{|c|}{ Relative error (\%) } \\
\hline $\mathrm{U}(\mathrm{VI})$ & $\operatorname{Th}(\mathrm{IV})$ & $\mathrm{U}(\mathrm{VI})$ & $\operatorname{Th}(\mathrm{IV})$ & $\mathrm{U}(\mathrm{VI})$ & $\operatorname{Th}(\mathrm{IV})$ \\
\hline 1.908 & 0.464 & $1.896(99.4)$ & $0.460(99.0)$ & -0.62 & -0.86 \\
\hline 1.908 & 0.928 & $1.900(99.6)$ & $0.930(100.2)$ & -0.42 & 0.21 \\
\hline 1.908 & 1.392 & $1.901(99.6)$ & $1.395(100.2)$ & -0.36 & 0.26 \\
\hline 1.908 & 1.856 & $1.898(99.4)$ & $1.855(99.9)$ & -0.52 & -0.05 \\
\hline 1.908 & 2.320 & $1.910(100.1)$ & $2.340(100.8)$ & 0.10 & 0.86 \\
\hline 1.908 & 4.640 & $1.898(99.4)$ & $4.650(100.2)$ & -0.52 & 0.21 \\
\hline 0.238 & 1.856 & $0.234(98.3)$ & $1.854(99.8)$ & -1.60 & -0.1 \\
\hline 0.476 & 1.856 & $0.468(98.3)$ & $1.849(99.6)$ & -1.60 & -0.37 \\
\hline 0.952 & 1.856 & $0.960(100.8)$ & $1.858(100.1)$ & 0.84 & 0.10 \\
\hline 1.428 & 1.856 & $1.432(100.3)$ & $1.848(99.5)$ & -0.28 & -0.43 \\
\hline 1.908 & 1.856 & $1.860(97.7)$ & $1.857(100.0)$ & -2.50 & 0.05 \\
\hline 2.380 & 1.856 & $2.400(100.8)$ & $1.846(99.4)$ & 0.84 & -0.53 \\
\hline
\end{tabular}

${ }^{*}$ Average of four determinations.

TABLE 13: Simultaneous determination of uranium and thorium in ore samples.

\begin{tabular}{|c|c|c|c|c|c|c|}
\hline \multirow{3}{*}{ Ore sample (composition) } & \multicolumn{4}{|c|}{ Amount of metal ion (ppm) } & \multicolumn{2}{|c|}{ Relative error } \\
\hline & \multicolumn{2}{|c|}{ Certified } & \multicolumn{2}{|c|}{ Found } & \multirow[b]{2}{*}{$\mathrm{U}(\mathrm{VI})$} & \multirow[b]{2}{*}{ Th(IV) } \\
\hline & $\mathrm{U}(\mathrm{VI})$ & $\operatorname{Th}(\mathrm{IV})$ & $\mathrm{U}(\mathrm{VI})$ & $\operatorname{Th}(\mathrm{IV})$ & & \\
\hline $\begin{array}{l}\text { 20283 MALINIM-G (Granite), (ppm) } \\
{[\mathrm{Eu}(0.35), \mathrm{F}(4200), \mathrm{Ga}(27), \mathrm{Gd}(14), \mathrm{Hf}(12), \mathrm{Li}(12),} \\
\mathrm{Lu}(2), \mathrm{Mo}(3), \mathrm{Nb}(53), \mathrm{d}(22), \mathrm{Tb}(3), \mathrm{U}(15), \mathrm{V}(2), \\
\mathrm{Yb}(14.2), \mathrm{Zn}(50), \mathrm{Zr}(300)]\end{array}$ & 15 & 51 & 14.85 & 52.68 & -0.01 & 0.032 \\
\hline $\begin{array}{l}\text { 20283 MALINIM-L (Lujavrite), (ppm) } \\
{[\mathrm{Eu}(1.2), \mathrm{F}(4400), \mathrm{Ga}(54), \mathrm{f}(190), \mathrm{Li}(48), \mathrm{Lu}(0.4),} \\
\mathrm{Mo}(4), \mathrm{Nb}(960), \mathrm{Nd}(22), \mathrm{Tb}(0.7), \mathrm{U}(14), \mathrm{V}(81) \\
\mathrm{Yb}(3), \mathrm{Zn}(400)]\end{array}$ & 14 & 66 & 14.46 & 64.68 & 0.03 & -0.02 \\
\hline
\end{tabular}

TABLE 14: Determination of uranium and thorium in spiked water samples.

\begin{tabular}{|c|c|c|c|c|c|c|}
\hline \multirow{3}{*}{ Water sample } & \multicolumn{4}{|c|}{ Amount $\left(\mu \mathrm{g} \mathrm{mL}^{-1}\right)$} & \multicolumn{2}{|c|}{ Recovery (\%) } \\
\hline & \multicolumn{2}{|c|}{ Spiked } & \multicolumn{2}{|c|}{ Found $(n=4) \pm \mathrm{SD}$} & \multirow[b]{2}{*}{$\mathrm{U}(\mathrm{VI})$} & \multirow[b]{2}{*}{ Th(IV) } \\
\hline & $\mathrm{U}(\mathrm{VI})$ & $\operatorname{Th}(\mathrm{IV})$ & $\mathrm{U}(\mathrm{VI})$ & $\operatorname{Th}(\mathrm{IV})$ & & \\
\hline \multirow{3}{*}{ Tap water } & 0.50 & 1.45 & $0.48 \pm 0.02$ & $1.48 \pm 0.03$ & 96.0 & 102 \\
\hline & 1.40 & 2.60 & $1.45 \pm 0.01$ & $2.52 \pm 0.01$ & 103.6 & 96.9 \\
\hline & 2.00 & 3.50 & $2.04 \pm 0.22$ & $3.38 \pm 0.04$ & 102.0 & 96.6 \\
\hline \multirow{2}{*}{ Bore well water } & 0.80 & 3.80 & $0.83 \pm 0.004$ & $3.90 \pm 0.03$ & 103.7 & 102.6 \\
\hline & 2.40 & 2.50 & $2.48 \pm 0.05$ & $2.44 \pm 0.06$ & 103.3 & 97.6 \\
\hline \multirow{4}{*}{ River water } & 0.45 & 0.60 & $0.44 \pm 0.01$ & $0.63 \pm 0.03$ & 97.7 & 105.0 \\
\hline & 0.80 & 1.40 & $0.84 \pm 0.03$ & $1.45 \pm 0.02$ & 105.0 & 103.6 \\
\hline & 1.50 & 2.90 & $1.48 \pm 0.02$ & $2.83 \pm 0.06$ & 98.6 & 97.6 \\
\hline & 2.20 & 3.80 & $2.14 \pm 0.03$ & $3.85 \pm 0.04$ & 97.3 & 101.3 \\
\hline
\end{tabular}




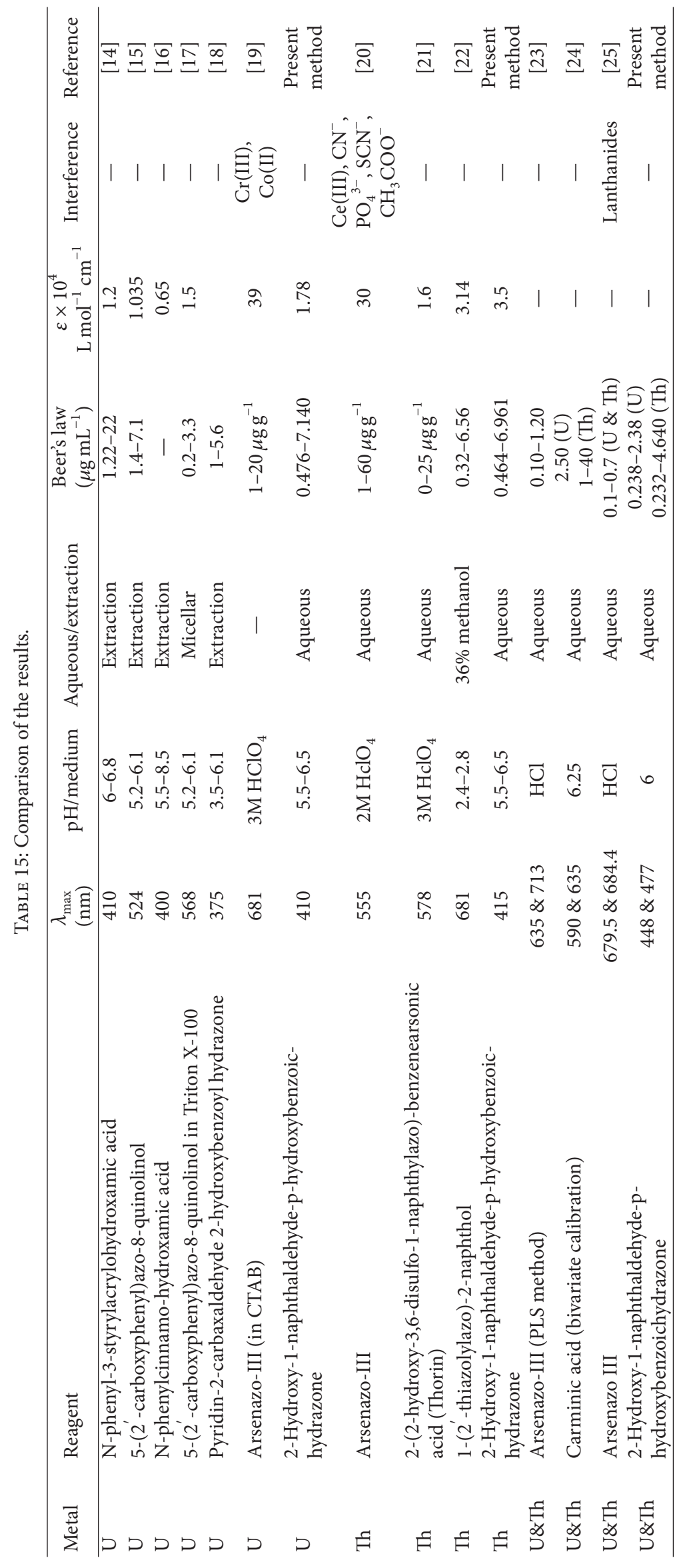


coefficients of the prepared calibration plots were calculated and presented in Table 11. The data in table indicate that the presence of $\mathrm{Th}(\mathrm{IV}) / \mathrm{U}(\mathrm{VI})$ is not influencing the calibration plot of $\mathrm{U}(\mathrm{VI}) / \mathrm{Th}(\mathrm{IV})$ to any significant extent. This allows the determination of $\mathrm{U}(\mathrm{VI})$ and $\mathrm{Th}(\mathrm{IV})$ in their mixtures without any significant error and without the need for their prior separation.

$\mathrm{U}(\mathrm{VI})$ and Th(IV) were mixed in different proportions and then treated with required amount of $\mathrm{HNAHBH}$ in the presence of buffer solution ( $\mathrm{pH} 6.0$ ) and $0.05 \%$ of CTAB and diluted to the volume in $10 \mathrm{~mL}$ volumetric flasks. The secondorder derivative spectra for these solutions were recorded (350-600 nm), and the derivative amplitudes were measured at $477 \mathrm{~nm}$ and $448 \mathrm{~nm}$. The amounts of U(VI) and Th(IV) taken in the mixtures were calculated from the measured derivative amplitudes using the respective predetermined calibration plots. The results obtained along with the recovery percentage and relative errors are presented in Table 12, which indicate the usefulness of the proposed method for the simultaneous determination of $\mathrm{U}(\mathrm{VI})$ and $\mathrm{Th}(\mathrm{IV})$.

3.4.3. Application of Proposed Simultaneous Method. $0.5 \mathrm{~mL}$ of the prepared ore samples and suitable volumes of water samples was analyzed by the proposed second-order derivative spectrophotometric method using HNAHBH and the results obtained and relative errors are tabulated in Tables 13 and 14.

\section{Conclusions}

The analytical results evaluated in the present paper in direct, derivative, and simultaneous methods were compared with those reported in some of the recently reported methods and presented in the Table 15. The comparison of the results indicate that the proposed method for the determination of uranium is more sensitive than number of reported methods [14-18] and more selective than the method reported by Khan et al. [20]. Regarding the determination of thorium the present method is more sensitive than those reported by Khan et al. [21], Sharma and Eshwar [22]. The results obtained in the simultaneous determination of $\mathrm{U}(\mathrm{VI})$ and Th(IV) are well comparable with the reported methods [23-25]. Above all most of the reported methods involve extraction in spurious organic solvents, whereas the present reported methods are simple, nonextractive, and reasonably accurate methods.

\section{Acknowledgment}

The authors gratefully acknowledge Sri Krishnadevaraya University, Anantapur, India for supporting the present work.

\section{References}

[1] M. Ivanovic and R. Harman, Application to Earth, Marine, and Environmentalm Science, Uranium series Disequilibrium, Chapter 4, Oxford Science Publications, 2nd edition, 1992.
[2] K. Bril and S. Holzer, "Determination of uranium in zirconium ores: a modification of the stannous chloride method," Analytical Chemistry, vol. 33, no. 1, pp. 55-58, 1961.

[3] O. Fujino, S. Umetani, E. Ueno, K. Shigeta, and T. Matsuda, "Determination of uranium and thorium in apatite minerals by inductively coupled plasma atomic emission spectrometry with solvent extraction separation into diisobutyl ketone," Analytica Chimica Acta, vol. 420, no. 1, pp. 65-71, 2000.

[4] S. Joannon, P. Teluk, and C. Pin, "Determination of U and Th at ultra-trace levels by isotope dilution inductively coupled plasma mass spectrometry using a geyser-type ultrasonic nebulizer: application to geological samples," Spectrochimica Acta B, vol. 52, pp. 1783-1789, 1997.

[5] B. F. Liu, L. B. Liu, and J. K. Cheng, "Separation and determination of thorium, uranium and mixed rare-earth elements as their UV/Vis absorbing complexes by capillary zone electrophoresis," Talanta, vol. 47, no. 2, pp. 291-299, 1998.

[6] E. Y. Hashem, Indian Journal of Chemistry A, vol. 33, p. 837, 1994.

[7] K. A. R. Idriss, M. M. Seleim, M. K. Hassan, M. S. Abu-Bakr, and H. Sedaira, "Ternary complexes in solution: mixed-ligand complexes of thorium(IV) with alizarin maroon and secondary ligands containing oxygen or nitrogen as donor atoms," The Analyst, vol. 110, no. 6, pp. 705-708, 1985.

[8] Y. K. Agarawal and U. Dayal, "Spectrophotometric determination of trace level thorium with n-phenylbenzohydroxamic acid," Journal of Radioanalytical and Nuclear Chemistry, vol. 90, no. 2, pp. 303-308, 1985.

[9] M. H. Khan, S. M. Hasany, M. A. Khan, and A. Ali, "Spectrophotometric determination of microamounts of thorium with disodium salt of 2-(2-hydroxy-3,6-disulfo-1naphthylazo)-benzenearsonic acid (Thorin) as a chromogenic reagent," Journal of Radioanalytical and Nuclear Chemistry, vol. 188, no. 5, pp. 341-353, 1994.

[10] A. W. Al-Shawi and R. Dahl, "Determination of thorium and uranium in nitrophosphate fertilizer solution by ion chromatography," Journal of Chromatography A, vol. 706, no. 1-2, pp. 175-181, 1995.

[11] J. H. Yoe, F. Will, and R. A. Black, "Colorimetric determination of uranium with dibenzoylmethane," Analytical Chemistry, vol. 25, no. 8, pp. 1200-1204, 1953.

[12] K. L. Cheng, "Determination of traces of Uranium with 1-(2Pyridylazo)-2-naphthol," Analytical Chemistry, vol. 30, no. 6, pp. 1027-1030, 1958.

[13] H. H. Gill, R. F. Rolf, and G. W. Armstrong, "Spectrophotometric determination of uranium with 1-(2-pyridylazo)-2naphthol," Analytical Chemistry, vol. 30, no. 11, pp. 1788-1792, 1958.

[14] Y. K. Agarwal, D. B. Upadhyaya, and S. P. Chudasama, "Liquidliquid extraction and spectrophotometric determination of uranium with n-phenyl-3-styrylacrylohydroxamic acid (PSAHA)," Journal of Radioanalytical and Nuclear Chemistry, vol. 170, no. 1, pp. 79-88, 1993.

[15] R. Saran and N. K. Baishya, "5-(2'-Carboxyphenyl)azo-8quinolinol as a sensitive reagent for extractive spectrophotometric determination of uranium in geological samples," Journal of Radioanalytical and Nuclear Chemistry, vol. 196, no. 2, pp. 363-368, 1995.

[16] B. S. Chandravanshi and T. Juhar, "Extraction and spectrophotometric determination of uranium(VI) with $N$-phenylcinnamohydroxamic acid," Journal of Radioanalytical and Nuclear Chemistry, vol. 210, no. 1, pp. 171-181, 1996. 
[17] R. Saran and N. K. Baishya, "Spectrophotometric determination of uranium with 5-(2'-carboxyphenyl)azo-8-quinolinol in the non-ionic micellar medium of Triton X-100," Journal of Radioanalytical and Nuclear Chemistry, vol. 220, no. 2, pp. 217-221, 1997.

[18] M. N. Bale and A. D. Sawanth, "Solvent extraction and spectrophotometric determination of uranium(VI) with pyridine-2-carboxaldehyde 2-hydroxybenzoylhydrazone," Journal of Radioanalytical and Nuclear Chemistry, vol. 247, no. 3, pp. 531-534, 2001.

[19] M. H. Khan, S. M. H. Bukhari, and A. Ali, "Spectrophotometric determination of uranium with arsenazo-III in the presence of $\mathrm{N}$-Cetyl- $\mathrm{N}, \mathrm{N}, \mathrm{N}$-trimethylammonium bromide as surfactant," Journal of Radioanalytical and Nuclear Chemistry, vol. 289, no. 1, pp. 113-119, 2011.

[20] M. H. Khan, A. Ali, and N. N. Khan, "Spectrophotometric determination of thorium with disodium salt of ArsenazoIII in perchloric acid," Journal of Radioanalytical and Nuclear Chemistry, vol. 250, no. 2, pp. 353-357, 2001.

[21] M. H. Khan, S. M. Hasany, M. A. Khan, and A. Ali, "Spectrophotometric determination of microamounts of thorium with disodium salt of 2-(2-hydroxy-3,6-disulfo-1naphthylazo)-benzenearsonic acid (Thorin) as a chromogenic reagent," Journal of Radioanalytical and Nuclear Chemistry, vol. 188, no. 5, pp. 341-353, 1994.

[22] C. D. Sharma and M. C. Eshwar, "Rapid spectrophotometric determination of thorium(IV) with 1-(2'-thiazolylazo)-2naphthol," Journal of Radioanalytical and Nuclear Chemistry, vol. 91, no. 2, pp. 323-328, 1985.

[23] P. D. Lopez-de-Alba, L. Lopez-Martinez, K. Wrobel, K. Wrobel, and J. Amador-Hernandez, "Simultaneous determination of uranium(IV) and thorium(IV) ions with Arsenazo III by partial least squares method," Journal of Radioanalytical and Nuclear Chemistry, vol. 220, no. 2, pp. 167-167, 1997.

[24] L. Lopez-Martinez, J. I. Gujman-Mar, and P. D. Lopez-de-Alba, "Simultaneous determination of uranium(VI) and thorium(IV) ions with carminic acid by bivariate calibration," Journal of Radioanalytical and Nuclear Chemistry, vol. 247, no. 2, pp. 413-417, 2001.

[25] R. Kuroda, M. Kurosaki, Y. Hayashibe, and S. Ishimaru, "Simultaneous determination of uranium and thorium with Arsenazo III by second-derivative spectrophotometry," Talanta, vol. 37, no. 6, pp. 619-624, 1990.

[26] A Guide To Practical Radio Chemistry, Mir Publisher, Moscow, Russia, 1984.

[27] N. Pourezza, H. Parsham, and P. Mirzavand, "Flotationspectrophotometric determination of trace amounts of thorium," Journal of Chinese Chemical Society, vol. 56, no. 4, pp. 785-788, 2009.

[28] B. Sadia, N. Haq, and T. M. Bhatti, International Journal of Agriculture and Biology, vol. 2, p. 1, 2000.

[29] A. Uyanik, N. Tinkilic, M. Odabasogulu, and H. Karaka, "Spectrophotometric determination of Uranium in waste water of phosphoric acid and fertilizer manufacturing process," Turkish Journal of Chemistry, vol. 23, pp. 275-284, 1999.

[30] A. M. Abdallah, M. A. Akl, and D. S. Ismail, "Simultaneous preconcentration flotation-separation and spectrophotometric determination of thorium, lanthanum and yttrium in some geological and enviromental samples," Journal of the Iranian Chemical Society, vol. 1, no. 1, pp. 79-87, 2004.

[31] N. K. Agnihotri, V. K. Singh, and H. B. Singh, "Simultaneous derivative spectrophotometric determination of thorium and uranium in a micellar medium," Talanta, vol. 40, no. 12, pp. 1851-1859, 1993.

[32] R. Kuroda, M. Kurosaki, Y. Hayashibe, and S. Ishimaru, "Simultaneous determination of uranium and thorium with Arsenazo III by second-derivative spectrophotometry," Talanta, vol. 37, no. 6, pp. 619-624, 1990.

[33] P. Yong, H. Eccles, and L. E. Macaskie, "Determination of uranium, thorium and lanthanum in mixed solutions using simultaneous spectrophotometry," Analytica Chimica Acta, vol. 329, no. 1-2, pp. 173-179, 1996. 

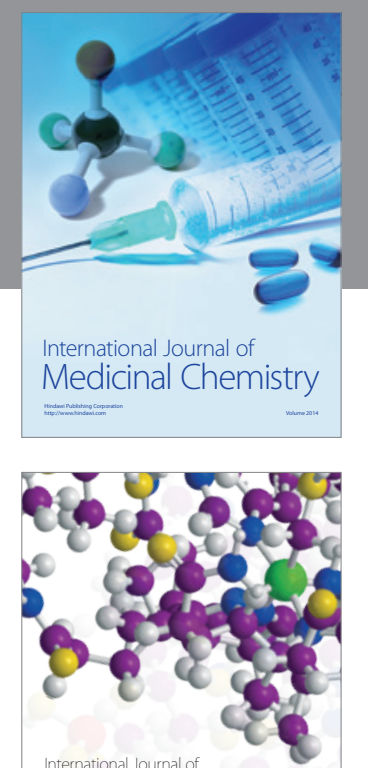

\section{Carbohydrate} Chemistry

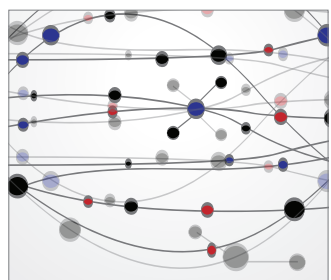

The Scientific World Journal
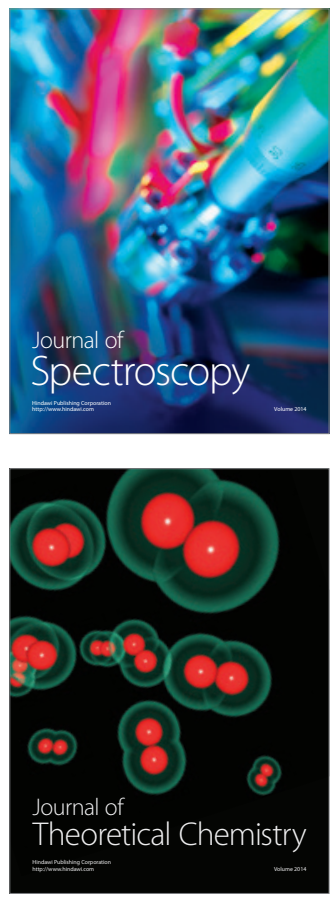
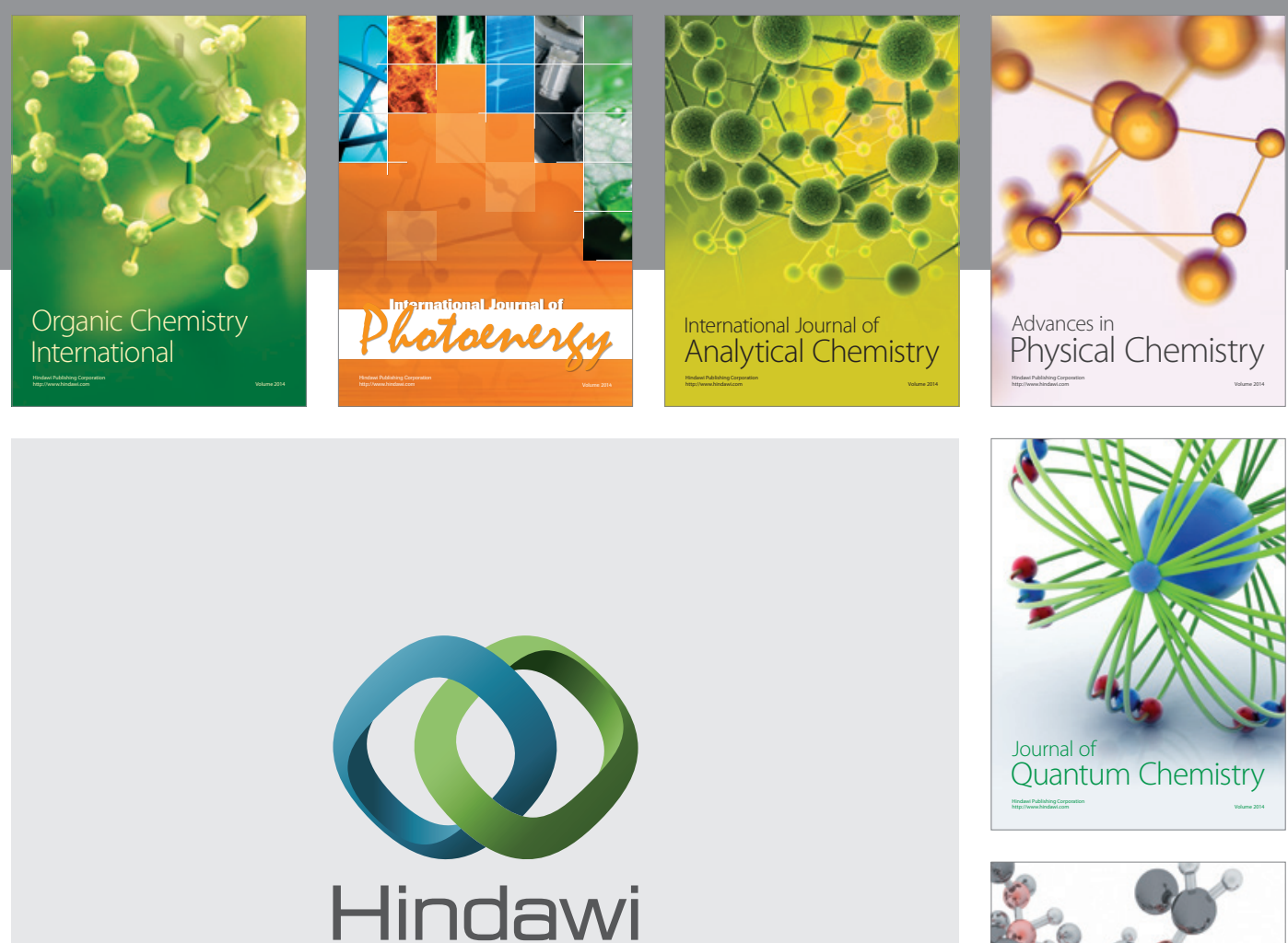

Submit your manuscripts at

http://www.hindawi.com

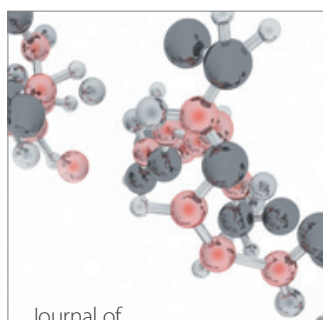

Analytical Methods

in Chemistry

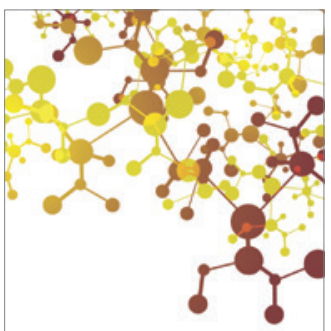

Journal of

Applied Chemistry

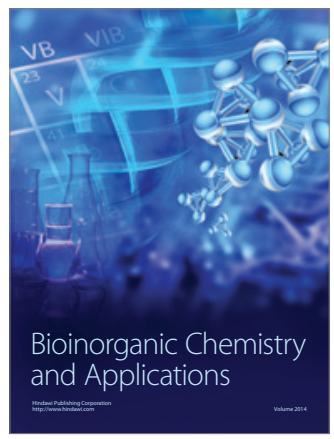

Inorganic Chemistry
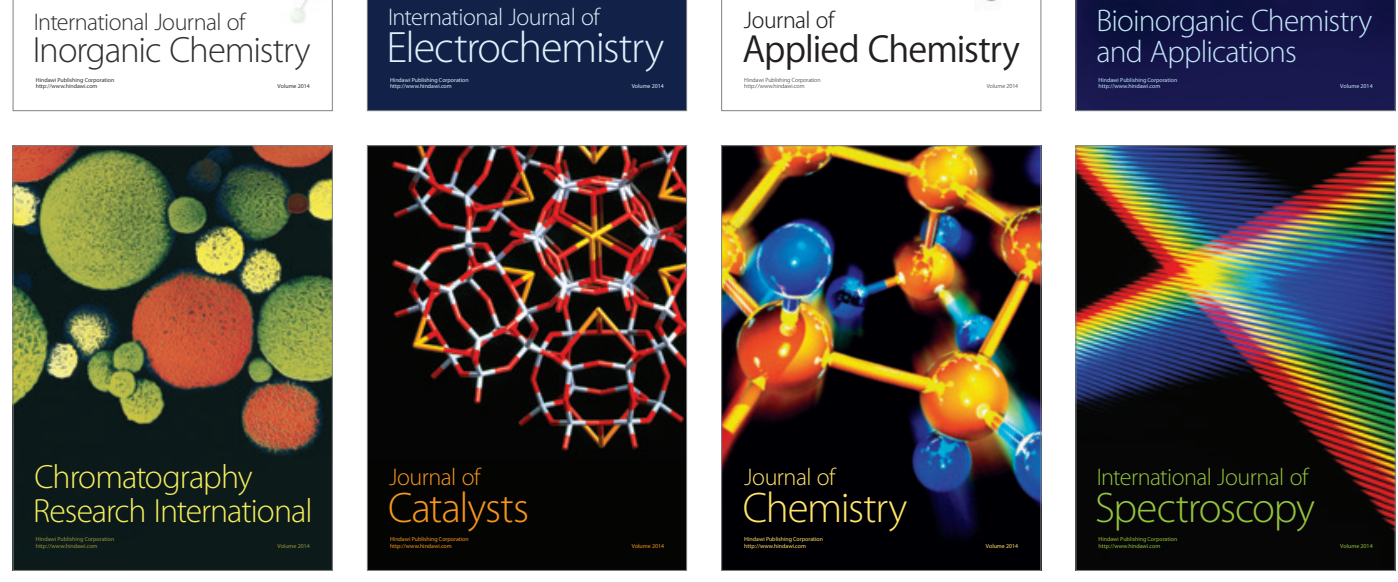